\title{
Hubungan Sikap dalam Tindakan Wanita Tunasusila Terhadap Penggunaan Kondom untuk Pencegahan HIV/Aids di Desa Kotakan Kecamatan Situbondo Kabupaten Situbondo
}

\author{
Dian Samtya , Dewi Rakhmawati
}

Stikes Maharani Malang, Universitas Islam Jember

Email: fidiatama@gmail.com ,drakhma23@yahoo.com

\begin{abstract}
Abstrak
Wanita tunasusila rentan tertular penyakit menular seksual dan HIV/AIDS. HIV/AIDS merupakan salah satu penyakit yang menyebabkan angka kematian yang tinggi dan jumlah penderita yang meningkat dalam waktu singkat. Penggunaan Kondom dapat mencegah penularan tersebut, tetapi tidak semua wanita tunasusila selalu menggunakan kondom saat melayani pelanggan. Penelitian ini bertujuan untuk mengetahui hubungan sikap dan tindakan terhadap penggunaan kondom. Penelitian ini merupakan penelitian survei analitik dengan menggunakan pendekatan cross sectional. Variabel independen adalah sikap terhadap penggunaan kondom. Variabel dependen adalah penggunaan kondom. Populasi yang digunakan adalah semua wanita Tunasusila di Desa Kotakan Kecamatan Situbondo Kabupaten Situbondo yaitu sebanyak 112 orang. Sementara sampel yang diambil sebesar 88 responden dengan teknik sampling random sampling. Hasil analisis data didapatkan sebagian besar sikap wanita tunasusila terhadap penggunaan kondom adalah negatif $(52,3 \%$.). Sementara tindakan penggunaan kondom sebagian besar wanita tunasusila kadang-kadang menggunakan kondom (32\%). Hasil uji chi square didapat $\mathrm{p}$ value sebesar $(0,044)<\mathrm{a}(0,05)$, maka $\mathrm{H} 1$ diterima atau hubungan antara sikap dengan penggunaan kondom pada wanita tunasusila di Desa Kotakan Kecamatan Situbondo Kabupaten Situbondo. Kesimpulan penelitian ini adalah ada hubungan sikap dengan tindakan pada wanita tuna susila terhadap penggunaan kondom untuk pencegahan hiv/aids di Desa Kotakan Kecamatan Situbondo Kabupaten Situbondo. Kata Kunci: Sikap, Kondom, Wanita Tunasusila.
\end{abstract}

\begin{abstract}
Attitude Relationships With Women prostitutes Measures Against Condom Use for Preventing HIV / AIDS Desa Kotakan Village of Situbondo regency. Female prostitutes vulnerable to contracting sexually transmitted diseases and HIV / AIDS. HIV / AIDS is a disease that causes high mortality and an increased number of people in a short time. The use of condoms can prevent transmission, but not all women are prostitutes always use condoms when serving customers. This study aimed to determine the relationship of attitudes and actions towards the use of condoms. This study is an analytic survey with cross sectional approach. The independent variable is the attitude towards the use of condoms. The dependent variable is the use of condoms. The population is all women prostitutes in the Kotakan Village District Situbondo as many as 112 people. While samples taken by 88 respondents with sampling random sampling technique. The results of the analysis of data obtained mostly female prostitutes attitudes toward condom use were negative (52.3\%.). While the act of using condoms most of the women prostitutes sometimes using condoms (32\%). The results obtained chi square test $p$ value of $(0.044)$ $<a(0.05)$, then $\mathrm{H1}$ is accepted or the relationship between attitudes to condom use in female prostitutes in the Kotakan Village District Situbondo. The conclusion of this study is no connection to the attitude and actions prostitutes to use condoms for the prevention of hiv / aids in the Kotakan Village District Situbondo.
\end{abstract}

Keywords: Attitude, condoms, prostitutes.

\section{Pendahuluan}

Wanita Tuna Susila (WTS) merupakan seseorang yang melakukan hubungan seksual dengan sesama atau lawan jenisnya secara berulang-ulang dan bergantian di luar perkawinan yang sah dengan tujuan mendapatkan imbalan uang materi atau jasa. Wanita tuna susila menjadi faktor penting di dalam penyebaran HIV/AIDS yang tidak dapat dipisahkan dengan kondisi prostitusi yang cukup eksis di Indonesia (Widyastuti, 2009). Hal tersebut membuat tingkat kemoralan bangsa Indonesia semakin terpuruk, terbukti dengan tingginya jumlah pekerja seks komersial akibatnya semakin banyak ditemukan penyakit menular seksual. WTS merupakan salah satu kelompok resiko tinggi tertular penyakit menular seksual (PMS) dan
HIV/AIDS (BKKBN, 2011).

HIV diketahui sebagai virus retro yang menginfeksi sistem imun terutama sel CD4+ (Baratawidjaja, 2006). Menurut Djuanda (2008), HIV adalah virus yang menyebabkan AIDS (Acquired Immune Deficiency Syndrome). AIDS sendiri didefinisikan sebagai syndrome/kumpulan gejala penyakit yang menyerang sistem kekebalan tubuh manusia.

Pendapat para ahli epidemiologi Indonesia dalam pembahasannya tentang kecenderungan HIV/AIDS, jumlah kasus AIDS di tahun 2010 menjadi 400.000 orang dengan kematian 100.000 orang .Pada tahun 2015 mendatang, diperkirakan kasus AIDS akan mencapai 1 juta orang dengan kematian 350.000 orang (Komunitas AIDS Indonesia, 2011). 
Kabupaten Situbondo dinilai menjadi salah satu penyumbang kasus HIV/AIDS di Jawa Timur. Berdasarkan data mapping per Juni 2010 yang dilakukan Lembaga Swadaya Masyarakat Simphoni Akar Rumput (LSM SAR), di Kabupaten Situbondo terdeteksi atau tercatat 17 hotsphot potensi penyebaran Infeksi Menular Seksual (IMS) dan orang yang hidup dengan HIV/AIDS tercatat 69 orang. Sedangkan data dari Dinas Kesehatan (Dinkes) Kabupaten Situbondo menerangkan dari tahun 2003 hingga 2010 ditemukan 45 kasus HIV/AIDS. Untuk bulan Juni Tahun 2011 di Situbondo jumlah korban HIV/AIDS dalam satuan persentase yakni berkisar antara 30 hingga 35 persen (Septivirawan, 2011). Penderita HIV/AIDS ini sudah menjangkau seluruh lapisan masyarakat, termasuk lbu rumah tangga, kalangan PSK, sopir, tukang becak, mahasiswa, bahkan pelajar dan mayoritas penderita masih didominasi oleh PSK (Dinkes Situbondo, 2017).

Berdasarkan studi pendahuluan yang dilakukan di lokalisasi Gunung Sampan pada 20 wanita tuna susila, 15 diantaranya tidak pernah menggunakan kondom. Jumlah wanita tuna susila yang tidak menggunakan kondom memicu terhadap penularan HID/AIDS.

Perkembangan ekonomi dan pertumbuhan penduduk menjadi salah satu faktor munculnya faktor resiko tinggi infeksi HIV/AIDS termasuk makin maraknya lokasi beresiko. Lokasi beresiko tinggi terinfeksi HIV/AIDS di Situbondo adalah lokalisasi Prostitusi Gunung Sampan yang berada di Desa Kotakan Kecamatan Situbondo Kabupaten Situbondo. Keberadaan lokalisasi Gunung Sampan di Kabupaten Situbondo tidak diakui secara resmi oleh pemerintah kabupaten, sehingga mempersulit upayaupaya penanggulangan penularan HIV/AIDS. Salah satu upaya yang dapat dilakukan adalah menggunakan kondom setiap melakukan transaksi seksual dengan banyak pasangan seksual sesuai dengan Komitmen Sentani tentang penggunaan kondom $100 \%$ (condom use $100 \%$ ) pada lokalisasi (KPA Nasional, 2007).

Menurut Green dan Kreuter (2005) tindakan dipengaruhi oleh faktor predisposisi antara lain (pengetahuan, sikap dan unsurunsur lain yang ada dalam diri individu), faktor pendukung (tersedianya sarana kondom) dan faktor penguat (dukungan teman seprofesi, mucikari, petugas kesehatan dan LSM).

Walaupun sikap masih belum terwujud dalam suatu tindakan namun sikap dapat menjadi potensi keyakinan seseorang agar mempertimbangkan keuntungan dan kerugian dalam menggunakan kondom pada saat berhubungan seksual (Smet, 1994). Karena dengan adanya sikap dapat membuat seseorang menerima, merespon, menghargai dan bertanggung jawab menggunakan kondom agar terhindar dari penyakit HIV/AIDS. Melihat begitu besar bahaya yang dapat dimbulkan oleh HIV/AIDS dan perkembangannya di Kabupaten Situbondo serta ditambah oleh adanya tempat beresiko tinggi yaitu lokalisasi Gunung Sampan, kurangnya pengetahuan PSK tentang kondom dan lemahnya sikap PSK pada penggunaan kondom, maka peneliti tertarik untuk melakukan penelitian dengan mengambil judul "Hubungan Sikap Wanita Tunasusila Terhadap Penggunaan Kondom Untuk Pencegahan HIV/AIDS di Desa Kotakan Kecamatan Situbondo Kabupaten Situbondo.

\section{Metode Penelitian}

Jenis penelitian yang digunakan dalam penelitian ini adalah analitik korelasional yang mana penelitian ini bertujuan untuk mengetahui hubungan antara suatu variabel dengan variabel yang lain. Hal tersebut diusahakan dengan mengidentifikasi variabel yang ada pada pada suatu objek, kemudian diidentifikasi pula variabel lain yang ada pada objek yang sama dan dilihat apakah ada hubungan antara keduanya (Notoatmodjo, 2005). Penelitian ini menggunakan pendekatan Cross Sectional yang menekankan pada waktu pengukuran/observasi data variabel independen pada satu saat.

Populasi dalam penelitian ini adalah semua wanita tuna susila di Desa Kotakan KecamatanSitubondo Kabupaten Situbondo. Jumlah populasi yaitu sebesar 112 wanita tuna susila dari bulan Januari sampai bulan Juni 2018. Sampel dalam penelitian ini adalah sebagian wanita tuna susila di Desa Kotakan Kecamatan Situbondo Kabupaten Situbondo. Jumlah Sampel berdasarkan perhitungan rumus diperoleh sebanyak 88 responden dengan teknik sampling menggunakan simple random sampling yaitu pengambilan sampel dengan cara acak tanpa memperhatikan strata yang ada dalam anggota populasi. Selanjutnya data yang didapatkan dari penelitian akan diolah melalui langkah editing, coding, entry dan tabulating. Analisis data menggunakan analisis univariat untuk mengetahui karakteristik responden dan analisis bivariat menggunakan uji chi square dengan SPSS dengan taraf signifikan $5 \%(\alpha<0,05)$.

\section{Hasil Dan Pembahasan \\ Hasil}

Penelitian ini bertujuan mengetahui 
Hubungan Sikap dan Tindakan Wanita Tuna Susila Terhadap Penggunaan Kondom Untuk Pencegahan HIV/AIDS di Desa Kotakan Kecamatan Situbondo Kabupaten Situbondo dengan hasil sebagai berikut :

Data Umum

Kelompok Umur

Tabel 1 Distribusi frekuensi karakteristik responden berdasarkan umur di Desa Kotakan Kecamatan Situbondo Kabupaten Situbondo

\begin{tabular}{ccc}
\hline Kelompok Umur & Jml & Persentase (\%) \\
\hline$<20$ tahun & 18 & 20,5 \\
$21-30$ tahun & 57 & 64,8 \\
$>30$ tahun & 13 & 14,8 \\
\hline Total & 88 & 100,0 \\
\hline
\end{tabular}

Berdasarkan Tabel 1 dapat dilihat bahwa dari 88 responden hampir setengahnya berada pada kelompok umur 21 sampai dengan 25 tahun, yaitu sebanyak 39 orang $(44,3 \%)$.

Pendidikan

Tabel 2 Distribusi frekuensi karakteristik responden berdasarkan paritas di Desa Kotakan Kecamatan Situbondo Kabupaten Situbondo

\begin{tabular}{ccc}
\hline Pendidikan & Jumlah & $\begin{array}{c}\text { Persentase } \\
(\%)\end{array}$ \\
\hline Tidak Sekolah & 9 & 10,2 \\
SD & 11 & 12,5 \\
SLTP & 47 & 53,4 \\
SLTA & 21 & 23,9 \\
\hline Total & 88 & 100,0
\end{tabular}

Berdasarkan Tabel 2 dapat dilihat bahwa dari 88 responden hampir sepenuhnya memiliki pendidikan SLTP yaitu sebanyak 47 orang $(53,4 \%)$.Pembahasan

Berdasarkan tabel distribusi tentang pemberian ASI eksklusif didapatkan, dari 42 responden yang memberikan ASI secara eksklusif yaitu 19 responden $(45,2 \%)$, sedangkan yang tidak memberikan ASI secara eksklusif adalah 23 responden (54,8\%). Hasil penelitian di atas menunjukkan bahwa sebagian besar ibu tidak memberikan ASI eksklusif.

Data Khusus

Identifikasi Sikap Responden Terhadap Penggunaan Kondom

Tabel 3 Distribusi frekuensi responden berdasarkan Sikap Terhadap Penggunaan Kondom di Desa Kotakan Kecamatan Situbondo Kabupaten Situbondo

\begin{tabular}{|c|c|c|}
\hline Sikap & Jumlah & $\begin{array}{c}\text { Persentase } \\
(\%)\end{array}$ \\
\hline Positif & 42 & 47,7 \\
\hline Negatif & 46 & 52,3 \\
\hline Total & 88 & 100,0 \\
\hline
\end{tabular}

bahwa dari 88 responden lebih dari setengahnya bersikap negatif terhadap penggunaan kondom, yaitu sebanyak 46 orang $(52,3 \%)$.

Identifikasi Penggunaan Kondom

Tabel 4 Distribusi frekuensi responden berdasarkan Penggunaan Kondom di Desa Kotakan Kecamatan Situbondo Kabupaten Situbondo

\begin{tabular}{ccc}
\hline $\begin{array}{c}\text { Penggunaan } \\
\text { Kondom }\end{array}$ & Jumlah & $\begin{array}{c}\text { Persentase } \\
(\%)\end{array}$ \\
\hline Selalu & 31 & 35,2 \\
Kadang-Kadang & 32 & 36,4 \\
Tidak Pernah & 25 & 28,4 \\
\hline Total & 88 & 100,0
\end{tabular}

Berdasarkan Tabel 4 dapat dilihat bahwa dari 88 responden hampir setengahnya kadang-kadang menggunakan kondom, yaitu sebanyak 32 orang $(36,4 \%)$.

Analisis Data Hubungan Sikap dengan Penggunaan Kondom

Tabel 5 Tabel Silang Hubungan Sikap dengan Penggunaan Kondom di Desa Kotakan Kecamatan Situbondo Kabupaten Situbondo

\begin{tabular}{|c|c|c|c|c|c|c|c|c|}
\hline \multirow[b]{2}{*}{ Sikap } & \multicolumn{6}{|c|}{ Tindakan Penggunaan Kondom } & \multirow[b]{2}{*}{ jml } & \multirow[b]{2}{*}{$\%$} \\
\hline & $\begin{array}{l}\text { Tdk } \\
\text { Per } \\
\text { nah }\end{array}$ & $\%$ & $\begin{array}{c}\text { Kadang } \\
\text { Kadang }\end{array}$ & $\%$ & $\begin{array}{c}\text { Selal } \\
\mathrm{u}\end{array}$ & $\%$ & & \\
\hline $\begin{array}{l}\text { Positif } \\
\text { Negat } \\
\text { if }\end{array}$ & $\begin{array}{c}7 \\
18\end{array}$ & $\begin{array}{c}8 \\
20,5\end{array}$ & $\begin{array}{l}16 \\
16\end{array}$ & $\begin{array}{l}15.3 \\
16,7\end{array}$ & $\begin{array}{l}19 \\
12\end{array}$ & $\begin{array}{l}21.6 \\
13,6\end{array}$ & $\begin{array}{l}42 \\
46\end{array}$ & $\begin{array}{l}47.4 \\
52,3\end{array}$ \\
\hline Total & 25 & 28,4 & 32 & 36,4 & 31 & 35,2 & 88 & 100 \\
\hline
\end{tabular}

bahwa dari 46 responden dengan sikap negatif, sebagian besar tidak pernah menggunakan kondom yaitu sebanyak18 orang $(20,5 \%)$ dari total responden. Sedangkan responden yang bersikap positif sebagian besar selalu menggunakan kondom yaitu 19 orang $(21,6 \%)$.

Untuk menganalisis hubungan antara sikap dan penggunaan kondom di gunakan uji chi-square pada tingkat kemaknaan $95 \%$ dengan hasil nilai $X^{2}$ sebesar 6,252 pada degree of freedom atau derajat kebebasan (df) 2dengan nilai approximately signifikan ( $p$ value) sebesar 0,044 , di mana nilai $p$ value kurang dari batas kritis $\alpha=0,05$. Maka keputusan jawaban atas hipotesis yang diajukan adalah $\mathrm{H} 1$ diterima atau yang berarti ada hubungan antara sikap terhadap penggunaan kondom dengan penggunaan kondom pada wanita tuna susila di Desa Kotakan Kecamatan Situbondo Kabupaten Situbondo.

Pembahasan Identifikasi Responden Berdasarkan Umur 
Hasil penelitian menunjukkan bahwa sebagian besar responden berada dikelompok umur 21-30 tahun (64,8\%). Besarnya angka ini diperkirakan disebabkan oleh lingkungan sosial dan budaya yang sudah terbentuk secara turun temurun. Jika dihubungkan dengan hasil mengenai tindakan penggunaan kondom hal ini sangat sesuai sebab sebagian besar responden hanya kadang-kadang menggunakan kondom ketika melayani pelanggannya. Pada usia tersebut seseorang masih belum matang berpikir dan belum memiliki pengalaman hidup yang banyak sehingga kurang hati-hati atas dampak dari resiko pekerjaannya seperti penyakit kelamin, HIV/AIDS yang bisa membahayakan dirinya dan orang lain.

Selain hal tersebut, tingginya kelompok usia yang mendominasi lokalisasi Kotakan dan tidak selalu memakai kondom dalam memerikan pelayanan kepada pelanggan diperkirakan dipengaruhi oleh tingkat pendapatan / ekonomi. Mereka sulit mengeluarkan rupiah untuk membeli alat pengaman, hal ini dikarenakan mereka sangat membutuhkan uang tersebut untuk menyambung hidup keluarganya hari demi hari. Apalagi jika pelanggannya berkurang maka, semakin sulit mereka menggunakan kondom.

PSK atau WTS dan apapun istilahnya seharusnya dicarikan jalan keluar yang cerdas dan sehat. Meraka adalah dampak realitas sosial, efek domino dari keadaan tertentu yang sulit untuk keluar kecauli ada yang mengeluarkan, sebab mereka sebenarnya tidak tahan dan tidak mau bertahan dengn kondisi tersebut. Maka oleh karena itu kepada semua pihak baik yang jadi pelanggan atau yang membenci kegiatan tersebut hendaknnya di upayakan untuk selalu memperhatikan kesehatan dengan memperkecil penularannya. Bagi pemerintah setempat, agar kondisi tersebut tidak semakin menjamur dan mewabah ke berapa tempat lainnya, hendak hal itu segera dicarikan jalan keluar dengan memberikan mereka modal ketrampilan yang bisa memberikan manfaat positif bagi mereka. Identifikasi Responden Berdasarkan Pendidikan

Hasil penelitian menunjukkan bahwa sebagian berpendidikan SMP (53,4\%). Besarnya nagka ini diperkirakan dipengaruhi oleh lingkungan sosial masyarakat yang kurang peduli terhadap pendidikan. Hasil ini jika disesuaikan dengan sikap responden terhadap tindakan penggunaan kondom sangatlah sesuai, sebab sebagian besar sikap responden adalah negatif. Sikap merupakan manifestasi dari segala yang diketahui dan mereka akan berperilaku sesuai dengan apa yang mereka tahu. Sementara pengetahuan itu sendiri bisa dibetuk salah satunyanya dengan pendidikan. Semakin tinggi pendidikan sesorang maka kemungkinan memiliki pengetahuan yang baik. Jika hasil ini dikorelasikan dengan tingkat pengguaan kondom sangatlah ada keseuaian karena sebagian besar mereka kadang-kadang menggunakan kondom. Mereka tidak menggunakan atau jarang menggunakan kondom bisa dikarenakan tidak tahu manfaat dan fungsinya. Mereka yang tidak mengetahui fungsi dan kegunaannya otomatis akan mengganggap hal tersebut adalah pemborosaan. Sementara bagi beberapa yang lain menganggap bahwa penggunaan kondom sedikit mengurangi rasa enak ketika melayani pelanggan.

Sikap ataupun tindakan merupakan resnpon dari segla yang dipahami, dan setiap tidakan ataupun sikap mewakili segala sesuatu yang ia ketahui. Maka meningkatkan pengetahuan terhadap fungsi dan kegunaan kondom menjadi sangat penting mengingat mereka dengan dengan penyakit yang sangat mematikan di dunia. Harapan tersebut dapat terwujud manakala ada pihak yang peduli terhadap keadaan tersebut. Terutama dari pihak pemerintah setempat. Banyak hal yang bisa dilakukan pemerintah selain dari menggusurnya, seperti memberikan ketrampilan hidup, melakukan pemerikasaan gratis untuk mendeteksi adanya penyakit mematikan tersebut dan selalu menghimbau untuk tetap menjaga kesehatan dirinya dan orang lain.

Identifikasi Sikap Responden Terhadap Penggunaan Kondom

Hasil penelitian menunjukkan responden yang bersikap negatif frekuensinya lebih besar dari pada yang bersikap positif yaitu 52,3 \%. Hal ini menunjukkan bahwa penggunaan kondom yang merupakan keharusan bagi pelayanan di semua tempat lokalisasi masih belum dapat dijalankan dengan sepenuhnya.

Hal ini dapat disebabkan oleh banyak hal, menurut Notoatmodjo (2003), sikap dapat dipengaruhi oleh berbagai hal antara lain: pengetahuan, pengalaman pribadi, kebudayaan, orang lain yang dianggap penting, media massa, institusi/lembaga pendidikan agama dan faktor emosional.

Beberapa faktor yang disebutkan di atas, faktor pengetahuan, pengalaman pribadi dan faktor emosional merupakan faktor yang memegang peranan penting yang menyebabkan kegagalan dalam pembentukan sikap positif terhadap penggunaan kondom. 
Pengetahuan merupakan faktor yang menjadi pencetus utama pembentukan sikap, sebab pengetahuan dapat memberikan pemahaman terhadap suatu objek apakah itu baik bagi dirinya atau tidak. Dalam hal ini, wanita tuna susila yang mendapatkan informasi yang benar tentang penggunaan kondom, baik definisi, fungsi dan manfaat serta dampak dan resiko otomatis akan terpengaruh untuk bersikap positif. Sedangkan bagi yang kurang mendapatkan informasi akan terpengaruh sebaliknya.

Tingkat pengetahuan wanita tuna susila dapat disebabkan oleh tingkat pendidikan, hal ini sesuai dengan hasil penelitian, di mana jumlah wanita tuna susila yang tidak sekolah hingga 10,2 \%, yang lulus SD $12,5 \%$ dan yang lulus SLTP $53,4 \%$.

Pengalaman pribadi wanita tuna susila selama bertahun-tahun juga sangat menentukan, sebab wanita tuna susila merasa bahwa tanpa menggunakan kondom tidak terjadi apa-apa pada dirinya. Sedangkan faktor emosional jelas sangat menentukan, sebab wanita tuna susila dalam melayani pelanggan dimotivasi oleh faktor mencari uang untuk pemenuhan kebutuhan hidup sehari-harinya.

Pengalaman tersebut dapat dibuktikan dalam penelitian ini, di mana masih banyak wanita tuna susila yang berumur kurang dari 20 tahun, yaitu hingga $20,5 \%$. Sedangkan yang berusia lebih dari 30 tahun jumlahnya hanya $14,8 \%$.

Menurut Mar'at (1984) dalam Rahayuningsih (2008), komponen sikap antara lain komponen kognisi yang berhubungan dengan belief (kepercayaan atau keyakinan, ide dan konsep) yaitu persepsi, stereotipe, opini yang dimiliki individu mengenai sesuatu. Hubungannya dengan wanita tuna susila adalah persepsi dan opini terhadap penggunaan kondom yang salah. Persepsi dan opini bahwa penggunaan kondom tidak memberikan dampak atau manfaat yang baik, menjadi faktor yang berpengaruh dalam menyebabkan kurang dipatuhinya keharusan penggunaan kondom. Identifikasi Penggunaan Kondom

Hasil penelitian menunjukkan hasil bahwa sebagian besar yaitu $36,4 \%$ responden kadang-kadang menggunakan kondom. Tingginya angka ini diperkirakan dipengaruhi oleh faktor pendidikan wanita tuna susila tersebut yang kemungkinan mereka tidak mengetahui manfaat dan fungsi kondom terhadap resiko pekerjaannya.

$$
\text { Hasil penelitian sesuai dengan }
$$

pendapat Notoatmodjo (2003), yang menyatakan bahwa perilaku kesehatan pada dasarnya adalah suatu respon seseorang terhadap stimulus yang berkaitan dengan sakit dan penyakit, sistem pelayanan kesehatan, makanan, serta lingkungan. Dalam hal ini perilaku penggunaan kondom berkaitan dengan sakit dan penyakit yaitu penyakit menular seksual terutama penyakit HIV/AIDS.

Pengertian di atas dapat menunjukkan bahwa rendahnya tingkat penggunaan kondom dalam kalangan wanita tuna susila sangat dipengaruhi oleh pemahaman atau persepsi yang sangat rendah terhadap manfaat penggunaan kondom kondom. Sebagian dari wanita tuna susila tidak memahami secara benar bahwa kondom merupakan media yang dapat mencegah penularan penyakit menular seksual terutama HIV/AIDS.

Pernyataan ini didukung oleh teori yang juga disebutkan oleh Notoatodjo (2003) bahwa faktor determinan atau pembentuk perilaku antara lain: faktor pembawa (predisposing factors), yaitu didalamnya termasuk pengetahuan, sikap, kepercayaan, keyakinan, nilai-nilai dan lain sebagainya, faktor pendukung (enabling factor) yang terwujud dalam lingkungan fisik, sumber daya, tersedia atau tidak, Faktor pendorong (reinforcing factor) yang terwujud di dalam sikap dan perilaku petugas kesehatan maupun petugas lain, teman, tokoh yang semuanya bisa menjadi kelompok referensi dari perilaku masyarakattersedianya fasilitas dan sarana kesehatan.

Berdasarkan faktor - faktor di atas dapat disimpulkan bahwa perilaku seseorang atau masyarakat tentang kesehatan ditentukan oleh pengetahuan, sikap, kepercayaan, tradisi dari orang yang bersangkutan. Disamping itu ketersediaan fasilitas kesehatan danperilaku petugas kesehatan juga mendukung dan memperkuat terbentuknya perilaku.

Wanita tuna susila yang tidak mau menggunakan kondom, dapat disebabkan karena dia memang belum tahu manfaatnya (predisposing factor), atau karena tempat mendapatkan kondom yang sulit didapat (enabling factor) sebab lain bisa jadi karena petugas kesehatan di wilayah yang bersangkutan kurang memperkenalkan manfaat kondom atau pelanggan yang dilayani juga tidak bersedia menggunakan kondom (reinforcing factor).

Model di atas dengan jelas menggambarkan bahwa terjadinya perilaku secara umum tergantung faktor intern (dari dalam individu) dan faktor ekstern (dari luar individu) yang saling memperkuat. Maka sudah selayaknya kalau kita ingin merubah perilaku kita harus memperhatikan faktorfaktor tersebut di atas.

Besarnya wanita tuna susila tidak menggunakan kondom merupakan masalah 
besar yang harus mendapatkan perhatian dari berbagai pihak, terutama pemerintah daerah setempat. Jika hal ini terus dibiarkan maka akan mengancam dan memiliki kecenderungan terhadap penularan penyakit kelamin terutama penularan HIV/AIDS. Sehingga memperkecil tingkat resiko penularan HIV/AIDS menjadi tanggung jawab semua pihak terutama pelaku dalam hal ini PSK dan pelanggan. Pemerintah daerah setempat memiliki andil besar mengurangi penularan HIV/AIDS dengan melakukan penyuluhan mengenai kesehatan reproduksi dan memberikan pemahaman terkait pentingnya penggunaan kondom dalam melayani pelanggan.

Analisis Data Hubungan Sikap dengan Penggunaan Kondom

Hasil pada penelitian ini menunjukkan bahwa $p$ value $(0.044)<a(0.05)$ hal ini menunjukkan terdapat hubungan yang signifikan antara sikap terhadap kondom dengan penggunaan kondom pada wanita tuna susila. Hasil analisa data menunjukkan nilai chi-square hitung sebesar 6,252 > nilai tabel sebesar 5.591. Sehingga hubungan sikap dengan tindakan penggunaan kondom berarti signifikan atau nyata.

Hasil penelitian ini sesuai dengan teori Fishbein dan Ajzen (1975) serta Worchel dan Cooper (1983) yang menyatakan bahwa sikap dan perilaku bisa konsisten apabila sikap dan perilaku yang dimaksud adalah spesifik dan ada relevansinya satu dengan yang lain. Sikap dan perilaku sering dikatakan berkaitan erat, dan hasil penelitian juga memperlihatkan adanya hubungan yang kuat antara sikap dan perilaku. Menurut mereka, antara sikap dan perilaku terdapat satu faktor psikologis yang harus ada agar keduanya konsisten, yaitu niat (intention). Selanjutnya Worchel dan Cooper (1983) menambahkan bahwa sikap dengan perilaku memiliki keterkaitan atau konsisten dalam kondisi sebagai berikut, spesifikasi sikap dan perilaku, relevansi sikap terhadap perilaku, tekanan normatif, dan pengalaman.

Sikap adalah cara menempatkan atau membawa diri, atau cara merasakan, jalan pikiran, dan perilaku. Dalam hal ini sikap tidak dapat terlepas dari perilaku, artinya dimana seseorang bersikap menolak suatu objek ia akan cenderung untuk menghindari objek tersebut atau bahkan sebaliknya jika seseorang menerima objek tersebut cenderung individu tersebut untuk melakukannya atau mendekati objek tersebut. Begitu juga dengan perilaku wanita tuna susila dalam menggunakan kondom karena sikap merupakan respon dari segala yang diketahui oleh seseorang, mereka yang memiliki sikap positif cenderung memiliki pengetahuan yang baik sehingga terdapat kecenderungan untuk berperilaku sesuai apa yang diketahuinya.

Wanita tuna susila yang berperilaku menggunakan kondom mengetahui terhadap resiko yang disebabkan atas profesinya. Kesehatan merupakan harga mahal yang tidak bisa ditukar dengan kenikmatan sesaat, begitu juga dengan menjadi pekerja sek komersial bukan keinginan semua orang. Maka melihat hal itu secara utuh dan menyeluruh adalah sikap bijak bagi semua pihak. Dalam hal ini peneliti bukannya pro ataupun kontra, melainkan hanya berharap agar kondisi tersebut tidak semakin meresahkan masyarakat luas dengan isu HIV/AIDS. Kekawatiran ini bisa dicegah dengan perilaku seksual yang sehat dengan memperhatikan segala unsur kesehatan, misalnya dengan menggunakan kondom setiap kali melayani pelanggan, karena dengan kondom memperkecil angka penularannya. Maka bagi semua instansi pemerintah, jika keberadaan lokalisasi tidak bisa dipungkiri lagi, maka seyogyanya agar semua pihak membentengi diri dengan memperkecil penularannya. Para pelayan masyarakat terutama petugas kesehatan diharapkan agar selalu memberikan penyuluhan dan beberapa informasi terkait masalah HIV/AIDS dilingkungan lokalisasi.

\section{Kesimpulan Dan Saran}

Kesimpulan

1. Lebih dari sebagian wanita tuna susila $(52,3 \%)$ mempunyai sikap yang negatif terhadap penggunaan kondom.

2. Lebih dari sebagian wanita tuna susila (32\%) mempunyai perilaku penggunaan kondom kadang-kadang.

3. Terdapat hubungan antara sikap dengan tindakan terhadap penggunaan kondom pada wanita tuna susila di Desa Kotakan Kecamatan Situbondo kabupaten Situbondo yang artinya sikap positif terhadap penggunaan kondom akan mempengaruhi perilaku dalam menggunakan kondom.

Saran

1. Instansi kesehatan memberikan informasi tentang sikap dan tindakan wanita tuna susila di Desa Kotakan Kecamatan Situbondo tentang penggunaan kondom dalam upaya pencegahan penularan HIV/AIDS.

2. Hasil penelitian ini dapat dijadikan bahan masukan dalam perencanaan program tindakan upaya pencegahan penularan HIV/AIDS di Kabupaten Situbondo. 
3. Bagi Tenaga Kesehatan

4. Tenaga kesehatan lebih meningkatan pelayanan untuk memberikan penyuluhan pada kelompok resiko tinggi tertular HIV/AIDS tentang manfaat penggunaan kondom.

5. Bagi Masyarakat

6. Masyarakat terutama wanita tuna susila untuk meningkatkan kesadaran untuk menggunakan kondom dan menghindari perilaku-perilaku yang dapat meningkatkan resiko tertular penyakit HIV/AIDS.

\section{Daftar Pustaka}

Budiono, Irwan. Konsistensi penggunaan kondom oleh wanita pekerja seks/pelanggannya.

https://journal.unnes.ac.id/nju/index.php/k emas/article/view/2803 vol 7 No. 2

Baratawidjaja, K.G., 2006. Imunologi Dasar. Jakarta: FK UI, 349-357.

Badan Kependudukan dan Keluarga Berencana Nasional (BKKBN). 2011. Harus Berani Minta Suami Berkondom. http://www.bkkbn.go.id/beritadaerah/Page s/Harus-Berani-Minta-Suami-

Berkondom.aspx. Diakses Tanggal $4 \mathrm{Mei}$ 2012.

Djuanda, A., 2008. Acquired Immune Deficiency Syndrome. Dalam: Unandar Budimulja dan Sjaiful Fahmil Daili. IImu Penyakit Kulit dan Kelamin. Jakarta: FK UI, 427-432.

Green, W., and Kreuter, M.W., 2005. Health Program Planning; An Educational and Ecological Approach, Four edition, McGraw-Hill, New York. repository.usu.ac.id/bitstream/123456789/ 31120/2/Reference.pdf. Diakses tanggal 27 April 2012.

Joint United Nation Organization Programme on HIV/ AIDS (UNAIDS) and (WHO)., 2007. Aids Epidemic Update, 5564.http://avert.org/.Diakses tanggal 26 April 2012.

Joint United Nation Organization Programme on HIV/ AIDS (UNAIDS)., 2009. Worldwide HIV/ADIS Statistik. Geneva, Joint United Nation Organization Programme on HIV/ AIDS (UNAIDS). http://avert.org/.Diakses tanggal 26 April 2012.

Joint United Nation Organization Programme on HIV/ AIDS (UNAIDS)., 2010. 2008. World Health Organization UNAIDS Annual Report,
20.http://avert.org/.Diakses tanggal 26 April 2012.

Komisi Penanggulangan AIDS Nasional., 2002. Laporan Eksekutif Mentri Kesehatan Republik Indonesia Tentang Ancaman HIV/AIDS di Indonesia Lebih Nyata. Komisi Penanggulangan AIDS Indonesia, Jakarta.

Komisi Penanggulangan AIDS Nasional., 2007. Strategi Nasional Penanggulangan HIV/ AIDS 2007-2010. Kementerian Koordinator Bidang Kesejahteraan Rakyat. Diperoleh dalam: http://undp.or.id/programme/pro-poor/pdf. Diakses tanggal 26 April 2012.

Komisi Penanggulangan AIDS., 2010. Laporan Kementerian Kesehatan Triwulan Kedua 2010. Kementerian Koordinator Bidang Kesejahteraan Rakyat. http://aidsindonesia.or.id. Diakses tanggal 25 April 2012.

Komunitas AIDS Indonesia., 2011. Komunitas AIDS Indonesia. Diperoleh dalam: http://aids-ina.org. Diakses tanggal 25 April 2012.

Muninjaya., 1999. AIDS Masalah dan Kebijakan Penanggulangannya. Jakarta:EGC, 20-40.

Nakita. 2012. Cara Penggunaan Kondom yang Benar. http://id.shvoong.com/howto/health/2071618-cara-penggunaankondom-yang-benar/\#ixzz1 v0m6aOYa. Diakses tanggal 13/5/2012.

Nursalam, 2013, Metodologi Penelitian IImu Keperawatan, Edisi 3, Salemba Medika, Jakarta

Septivirawan A. 2011. Temuan LSM SAR, Korban HIV/AIDS Bulan Juni di Situbondo Sekitar $35 \quad$ Persen. http://kesehatan.kompasiana.com/seksolo gi/2011/06/21/temuan-lsm-sar-korbanhivaids-bulan-juni-di-situbondo-sekitar-35persen/.Diakses tanggal 27 April 2012.

Smet, B., 1994. Psikologi Kesehatan, Penerbit Gramedia, Jakarta. 